\title{
STUDIES ON THE SYNTHESIS OF UNSATURATED NUCLEOSIDE ANALOGS(Abstract_要旨)
}

$\operatorname{AUTHOR}(S)$ :

Yajima, Toshinori

\section{CITATION:}

Yajima, Toshinori. STUDIES ON THE SYNTHESIS OF UNSATURATED NUCLEOSIDE ANALOGS. 京都大学, 1970, 農学博士

\section{ISSUE DATE:}

1970-09-24

URL:

http://hdl.handle.net/2433/213479

RIGHT: 


\section{【238】}

氏名矢島俊典

学位の種類農学博士

学位記番号農 博 第 112 号

学位授与の日付 昭 和 45 年 9 月 24 日

学位授与の要件 学位規 則第 5 条第 1 項 該 当

研究科・専 攻農学研究科農芸化学専攻

学位論文題目 STUDIES ON THE SYNTHESIS OF UNSATURATED

NUCLEOSIDE ANALOGS

（不飽和ヌクレオシド類縁物質の合成に関する研究）

論文調查委員教授 小野寺幸之進教授中島 稔 教授緒方浩一

\section{論 文 内容 の 要 旨}

本諭文は不飽和ヌクレオシドの新しい合成法を開発し，それを用いて関逨化合物を合成するとともに， ヌクレオシド分子の糖部分に不飽和結合が生成する機構を論考した結果をまとめたものである。

$1 ， 2 ， 3 ， 4$ 一トラーO-アセチルーL一ラムノピラノース（1モル）とテオフィリン（1モル） とを $140 \sim 150^{\circ}$ で融解し，微量の $\mathrm{P}$ 一トルンスルホン酸を加えて減压下に30分間反応させる。乙机をエ タノールに溶解し再結すると m. p. 192 193ㅇ の結晶が得られた（収量 $25 \%$ )。との化合物は UV, IR,

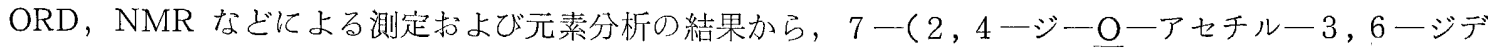

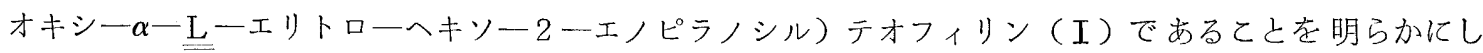
た。

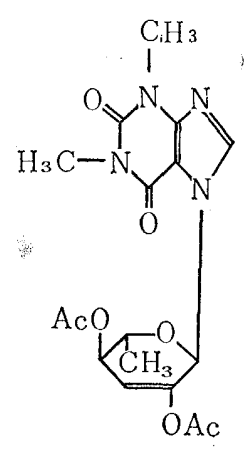

(I)

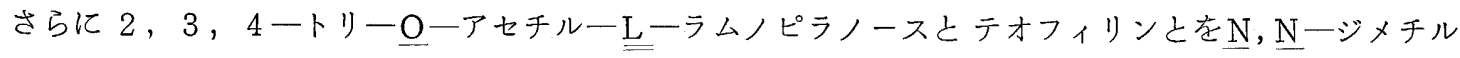
ホルムアミドに溶解し，五酸化りンを加えて $60 \sim 70^{\circ}$ で 141時間反応させた後，クロロホルム一水混合液 によって抽出し，エタノールから再結すると m. p. 192 193の結晶が得られた（収量 $5 \%$ )。上記之同様 の測定と分析ならびに混融試験の結果，Iと同一物質であるととが確認された。 
このような不飽和ヌクレオシドの生成機構，およびとの反応が他の糖と塩基との場合にも起とるかどう かを見るため以下の実験を行なった。

まず，上一フコースとテオフィリンとの融解反応では不飽和ヌクレオシドの生成は起てらなかった。 すなわち 6 一デオキシ基は 不飽和結合生成の要因ではないといえる。つぎに別法によって合成した 7 -

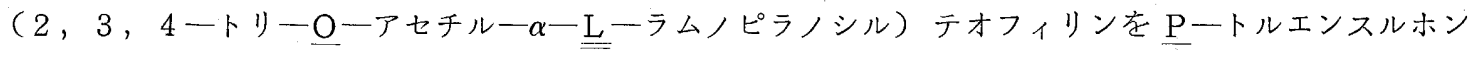
酸の存在下に，同じ条件で処理したが，糖部分の不飽和化は認められなかった。このととは不飽和結合が ヌクレオシドが合成される以前につくら机るとを示している。

さらに $1 ， 2 ， 3 ， 4$ 一テトラ一 $\mathrm{O}-$ 一七チル- $\mathrm{L}$-ラムノースを $120 \sim 130^{\circ}$ で融解し， $\underline{\mathrm{P}}$ 一トルエン スルホン酸を加えて減圧下に15分間 130 1 $140^{\circ}$ で反応させた。反応生成物をカラムクロマトグラフィーに かけて分画し，シロップが得ら扎た NMR，UV，IR などによる測定の結果，生成物は 2,4 - $\mathrm{O}$ 一

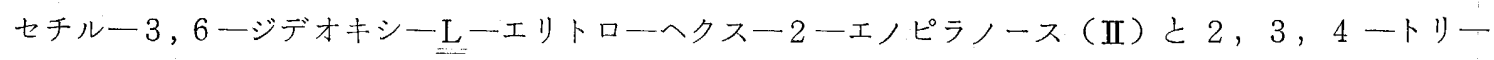

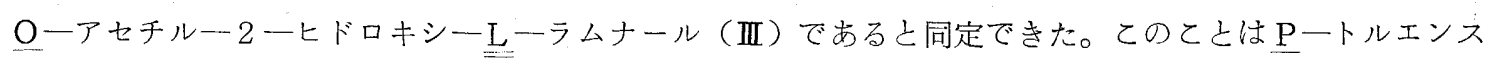
ルホン酸によって脱アシル化とともに二重結合が生成し，ついでテオフィリンとの縮合が起とることを立 証するむのである。な掞別の実験によって不飽和ヌクレオシド生成経路の中間体として亚が生成するとと を証明した。

この不飽和ヌクレオシドの 関連化合物として 7 - ( 2，4，6ートリ一O-ア七チルー3ーデオキシー $\alpha$ 一D一エリトローヘクスー2一エノピラノシル) テオフィリン，7-(2，4，6一トリーO-アセチル

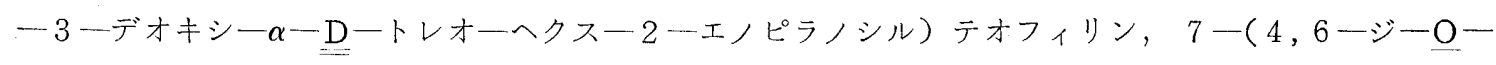
アセチルー2,3-ジデオキシー $\beta$-D-トレオーヘクスー2-エノピラノシル) テオフィリン， $7-(4$

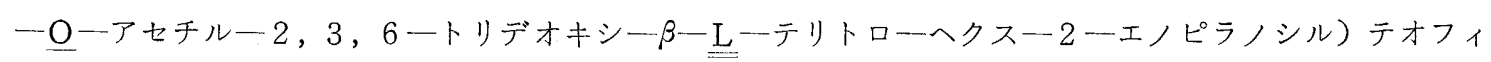

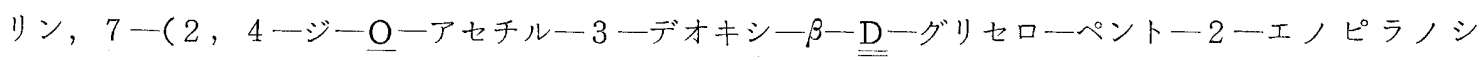
ル) テオフィリンなどを合成し，またとれら不飽和ヌクレオシドの糖部分の立体配座を明らかにした。

\section{論文蜜查の結果の要旨}

ヌクレオシド型抗生物質のなかにはブラストサイジン S やアングストマイシン A ように糖部分に不 飽和結合をもつものがあって，てのような不飽和ヌクレオシドは，その反応性，立体配座，生理作用，生 合成機構などの観点から興味ある物質群である。この型のヌクレオシドは, 飽和型ヌクレオシド合成の中 間体として単離されているが，合成化学的には研究が少なかった。

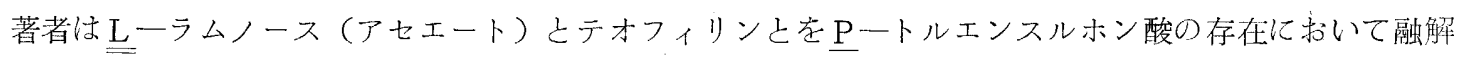
縮合させると，不飽和ヌクレオシドが合成されるという新方法を開発した。また $\mathrm{N}, \mathrm{N}$ 一ジメチルホルム アミドを溶媒とし，五酸化リンを脱水剂として用いて不飽和ヌクレオシドを合成する方法も開発した。

さらに，不飽和ヌクレオシドの生成機構を追求して，糖部分にまず不飽和結合が生成し，ついでヌクレ オシド結合がつくられることを明らかにするとともに，その理論的考察をしている。

この不飽和ヌクレオシドの関連化合物としてグリカルを出発物質しして数種類の新しい不飽和ヌクレオ シドを合成し，そ机らの糖部分の立体配座を明らかにした。 
とのように本研究は合成化学的にも生化学上でも重要な不飽和ヌクレオシドの合成法を開発するととも に，乙の物質群の化学に新しい知見を加えたむので，乙の分野の進展に寄与するとてろが大きい。 よって, 本論文は農学博士の学位論文として価値あるものと認める。 